$\mathrm{H}$ аружная терапия больных врожАенным булиезным эпиАермолизом

(С) Кубанов А.А., Чикин В.В., Карамова А.Э., Мончаковская Е.С. *

Государственный научный центр дерматовенерологии и косметологии

107076, Россия, г. Москва, ул. Короленко, д. 3, стр. 6

Врожденный буллезный эпидермолиз - генетически обусловленное заболевание, проявляющееся пузырными высыпаниями и эрозивно-язвенным поражением кожи и слизистых оболочек, требующее проведения наружной терапии. В обзоре литературы рассмотрены основные клинические проявления врожденного буллезного эпидермолиза и механизмы их развития, в соответствии с которыми выделены основные направления наружной терапии больных врожденным буллезным эпидермолизом - защита кожи от травмирования, ее увлажнение, стимуляция заживления эрозивно-язвенных дефектов кожи, предотвращение и борьба с инфицированием очагов поражения, устранение боли и зуда. Представлены лекарственные препараты, которые могут использоваться для наружной терапии больных врожденным буллезным эпидермолизом с учетом инфрормации о доступных лекарственных фрормах, способах использования, возрастных ограничениях, приведенной в инструкциях по их медицинскому применению. Обоснована необходимость использования в наружной терапии больных врожденным буллезным эпидермолизом препаратов для лечения ран и язв, антисептиков и дезинсрицирующих средств, антибиотиков и противомикробных средств, применяемых в дерматологии, а также средств, уменьшающих сухость кожи, интенсивность зуда и болевые ощущения.

Ключевые слова: врожденный буллезный эпидермолиз, наружная терапия, препараты для лечения ран и язв, антисептики, дезинфицирующие средства, антибиотики, противомикробные средства.

Конфрликт интересов: авторы данной статьи подтвердили отсутствие конфрликта интересов, о котором необходимо сообщить.

Источник фринансирования: работа выполнена и опубликована за счет фринансирования по месту работы авторов.

Для цитирования: Кубанов А.А., Чикин В.В., Карамова А.Э., Мончаковская Е.С. Наружная терапия больных врожденным буллезным эпидермолизом. Вестник дерматологии и венерологии. 2021;97(6):06-19.

doi: https://doi.org/10.25208/vdv1282 


\title{
opical treatment of inherited epidermolysis bullosa
}

\author{
(C) Alexey A. Kubanov, Vadim V. Chikin, Arfenya E. Karamova, Ekaterina S. Monchakovskaya*
}

State Research Center of Dermatovenereology and Cosmetology

Korolenko str., 3, bldg 6, 107076, Moscow, Russia

Inherited epidermolysis bullosa is a group of genetic skin disorders characterized by skin erosions, ulceration, skin and mucosal blistering requiring topical treatment. This review demonstrates major clinical manifestations of epidermolysis bullosa and its mechanisms of development. According to these features the main principles of topical treatment and drug therapy were developed, including physical protection from trauma, moisturizing, improvement of wound healing, prevention and management of infection, itch and pain management. Drug therapy is outlined with dosage forms, drug routes of administration, age restrictions indicated in the instruction for medical use for the medications that could be used in epidermolysis bullosa patients. The authors provide indications for clinical use of antiseptics, disinfectants, antibiotics, antimicrobial agents, emollient cream and drugs reducing itch and pain.

Keywords: inherited epidermolysis bullosa, topical treatment, wound care, antiseptics, disinfectants, antibiotics and antimicrobial agents in dermatology.

Conflict of interest: the authors declare that there are no obvious and potential conflicts of interest associated with the publication of this article.

Source of funding: the work was done and published with funding at the place of work of the authors.

For citation: Kubanov AA, Chikin VV, Karamova AE, Monchakovskaya ES. Topical treatment of inherited epidermolysis bullosa. Vestnik Dermatologii i Venerologii. 2021;97(6):06-19. doi: https://doi.org/10.25208/vdv1282 
Врожденный буллезный эпидермолиз представляет собой группу наследственных заболеваний, в основе развития которых лежит генетический дефект структурных белков, обеспечивающих устойчивость кожи и слизистых оболочек к механическим воздействиям. В коже эти белки располагаются в цитоплазме и клеточной стенке кератиноцитов, в светлой и плотной пластинке дермо-эпидермального соединения. Их последовательное связывание друг с другом обеспечивает прочное соединение эпидермиса, представляющего собой эпителиальную ткань, и дермы, основу которой составляет соединительная ткань.

Мутации генов, кодирующих белки, ассоциированные с развитием врожденного буллезного эпидермолиза, могут иметь различные неблагоприятные последствия. Вследствие патогенных мутаций возможны синтез нефункционального белка, синтез белка с сохраненной функцией, но чрезмерно быстро подвергающегося протеолитическому распаду, уменьшение продукции белка, вплоть до его полного отсутствия. Все это приводит к ослаблению связи между эпидермисом и дермой и уменьшению устойчивости кожи и слизистых оболочек к механическим воздействиям. Даже незначительная механическая травма может вызвать у больного врожденным буллезным эпидермолизом расщепление эпидермиса и дермы на уровне расположения мутантного белка в коже. В зависимости от уровня расщепления выделяют 4 типа врожденного буллезного эпидермолиза - простой, пограничный, дистрофический и синдром Киндлера [1].

Простой врожденный буллезный эпидермолиз характеризуется расщеплением и формированием полостей на уровне базального слоя эпидермиса. Наиболее часто его развитие обусловлено мутациями генов, кодирующих белки промежуточных фриламентов кератиноцитов - кератины 5-го и 14-го типов [2, 3]. Известны случаи простого врожденного буллезного эпидермолиза, вызванного мутациями генов, кодирующих линкерные белки цитоскелета (цитолинкерные белки), которые обеспечивают взаимодействие между промежуточными фриламентами и клеточной стенкой кератиноцита. К этим белкам относятся плектин и антиген буллезного пемфигоида 230 (белок ВР230). К развитию простого врожденного буллезного эпидермолиза приводят также генетические дефекты белков экзофрилина-5, KLHL24 (24-го члена семейства чашеобразных белков), CD151 (тетраспанина 24) [4-6]. Иногда развитие простого врожденного эпидермолиза обусловлено мутациями белков, основная часть которых располагается в светлой пластинке базальной мембраны, но имеющих домен, проникающий в цитоплазму базальных кератиноцитов. С мутациями цитоплазматического домена белков светлой пластинки связывают случаи простого типа болезни вследствие мутаций интегрина $\alpha 6 \beta 4$ и коллагена 17-го типа [7].

Пограничный врожденный буллезный эпидермолиз характеризуется расщеплением в области светлой пластинки базальной мембраны в результате мутаций генов, кодирующих цепи $\alpha 3, \beta 3$ и $\gamma 2$ ламинина-332, $\alpha 6$ и $\beta 4$-субъединицы интегрина $\alpha 6 \beta 4$ и коллагена 17-го типа $[8,9]$. При дистрофрическом врожденном буллезном эпидермолизе расщепление с формированием полостей происходит в области плотной пластики базальной мембраны вследствие мутаций гена коллагена 7-го типа [9]. Синдром Киндлера характеризуется расщеплением, происходящим в различных слоях эпидермиса, и обусловлен мутациями гена, кодирующего белок киндлин-1 [10].
В связи с тем, что в основе развития всех типов врожденного буллезного эпидермолиза лежит ослабление связи между эпидермисом и дермой, все они характеризуются общим клиническим признаком - появлением на коже или слизистых оболочках пузырей даже после незначительной механической травмы. На месте пузырей впоследствии образуются эрозии или язвы. В случае трения кожи больного врожденным буллезным эпидермолизом возможно образование эрозий вследствие отслойки эпидермиса без формирования пузыря.

Тяжесть поражения кожи при различных типах врожденного буллезного эпидермолиза очень различна [11]. Заболевание может иметь легкое течение с нечастым появлением ограниченных, быстро регрессирующих высыпаний. Легкое течение болезни наблюдается при локализованном простом или доминантном дистрофрическом врожденном буллезном эпидермолизе. В таких случаях заболевание не влияет на продолжительность жизни больных, которые редко обращаются за медицинской помощью. Намного чаще к врачу-дерматовенерологу обращаются пациенты с тяжелым течением врожденного буллезного эпидермолиза, которое характерно для пограничного и рецессивного дистрофического буллезного эпидермолиза. У этих пациентов отмечается значительное сокращение продолжительности жизни [12-14].

Тяжесть течения и выраженность клинических проявлений болезни врожденного буллезного эпидермолиза определяются различными факторами, среди которых важное значение имеет характер патогенной мутации [15]. Наиболее тяжелые проявления врожденного буллезного эпидермолиза ассоциируются с нонсенс-мутациями или делециями и вставками со сдвигом рамки считывания, приводящими к формированию преждевременного стоп-кодона. Эти мутации приводят к прекращению синтеза функционального белка, полное отсутствие которого ведет к выраженному уменьшению резистентности кожи и слизистых оболочек к механическим нагрузкам и, соответственно, к тяжелому течению болезни. В таких случаях пузыри возникают после минимального воздействия на кожу и слизистые оболочки, а высыпания носят распространенный характер. С другой стороны, следствием миссенсмутаций, приводящих к замене одной аминокислоты в полипептидной цепи белка на другую, или делеций без сдвига рамки считывания, которые ассоциированы с утратой части полипептидной цепи, является синтез функционального, но быстро разрушающегося белка или синтез белка с частичной утратой функции. В таких случаях возможно легкое течение болезни с ограниченными высыпаниями и быстро эпителизирующимися эрозиями.

Глубина образующегося дефекта кожи зависит от уровня расположения мутантного белка. Для простого врожденного буллезного эпидермолиза, при котором расщепление происходит на уровне базальных кератиноцитов, более характерно образование эрозий, а при дистрофическом типе болезни, который характеризуется расщеплением в нижней части базальной мембраны на границе с дермой, могут формироваться язвы.

Вследствие того, что незначительные механические травмы, повлекшие фрормирование у больных врожденным буллезным эпидермолизом образование дефектов кожи и слизистых оболочек, часто повторяются, однажды возникшие эрозии и язвы могут долго не заживать 
и существовать длительное время. Кроме того, некоторые белки, ассоциированные с развитием врожденного буллезного эпидермолиза, например, ламинин-332, коллагены 7-го и 17-го типов, участвуют в процессах репарации и восстановления целостности кожи, обеспечивая подвижность кератиноцитов, мигрирующих из края раны в ее центр во время заживления [16-19]. Генетически обусловленные дефекты этих белков еще в большей степени задерживают естественное заживление эрозий и язв и способствуют увеличению продолжительности их существования. Поэтому длительное заживление эрозий и язв является характерным признаком врожденного буллезного эпидермолиза, вызванного мутациями генов ламинина-332 и коллагенов 7-го и 17-го типов.

Патологические изменения кожи у больных врожденным буллезным эпидермолизом сопровождаются воспалительной реакцией, развитие которой характеризует первый этап заживления ран [20]. Как и раны, повреждения кожи при этом заболевании вызваны механическими воздействиями. Известно, что на ранних стадиях заживления ран высвобождается множество провоспалительных цитокинов, в том числе ФНО- $\alpha$, ИЛ-2, ИЛ-4, ИЛ-6 и ИЛ-8 [21].

Развитию воспалительной реакции в коже могут также способствовать генетически обусловленные изменения продукции структурного белка, ассоциированного с развитием врожденного буллезного эпидермолиза. В экспериментах получены данные о поВышении уровня продукции ФНО- $\alpha$ кератиноцитами, продуцирующими мутантный кератин 14 [22]. В коже мышей с мутацией K5-/- полное отсутствие экспрессии кератина 5-го типа сопровождалось увеличением продукции провоспалительных цитокинов ИЛ-6 и ИЛ-1 $\beta$ [23]. Важное значение в патогенезе тяжелого простого ВБЭ (ранее - ВБЭ Доулинга - Меары) придается увеличению продукции кератиноцитами ИЛ-1 $\beta$, который индуцирует диффреренцировку Th17-лимфоцитов, В то время как ИЛ-6 усиливает этот эффект [24, 25]. Это подтверждено результатами обследования больных тяжелым простым ВБЭ, показавшего повышенный уровень содержания Th17-цитокинов ИЛ-17, ИЛ-21 и ИЛ-22 в пораженной коже [26]. Продемонстрирована повышенная экспрессия ФНО- $\alpha$ и ИЛ-6 макрофрагами при синдроме Киндлера [27]. При рецессивном дистрофическом ВБЭ обнаружено повышение экспрессии генов рецепторов ИЛ-13 и ИЛ-4, участвующих в развитии аллергического воспаления и в формировании ощущения зуда [28].

В условиях воспалительной реакции в дерме больных врожденным буллезным эпидермолизом происходит активация фрибробластов, что приводит к повышенной продукции коллагена и формированию рубцовой ткани. Рубцевание особенно характерно для рецессивного дистрофического эпидермолиза, при котором формируются рубцовые контрактуры и псевдосиндактилии [29]. Дистрофиические процессы, происходящие в коже больных, могут стать причиной развития ее сухости. Возможно даже формирование очагов гиперкератоза, которые чаще всего образуются на ладонях и подошвах.

Поверхность эрозивно-язвенных дефектов кожи, особенно длительно существующих, легко колонизируется бактериями и грибами, что может привести к развитию клинически значимого инсекционного поражения кожи [30]. При посеве отделяемого с поверхности эрозий и язв по крайней мере один вид микроорганиз- мов был выделен у 152 из 158 обследованных больных врожденным буллезным эпидермолизом, а клинические признаки инфицирования эрозий и язв были обнаружены у 57\% из них [31]. Микроорганизмы, колонизирующие дефекты кожи у больных врожденным буллезным эпидермолизом, характеризуются значительным видовым разнообразием. Наиболее часто при посеве отделяемого из эрозий и язв пациентов с ВБЭ выделялся Staphylococcus aureus, обнаруженный у $86 \%$ пациентов. K часто выделяемым бактериям также были отнесены Pseudomonas aeruginosa (у 37\% пациентов), Streptococcus pyogenes (y 22\%), Corynebacterium spp. (у $20 \%$ и и Proteus spp. (у 11\%). Кроме того, из отделяемого с поверхности эрозий и язв выделялись коагулазонегативные стафилококки (7\%), Streptococcus agalactiae (группа В) (7\%), Serratia marcescens (5\%), Klebsiella pneumoniae (3\%), Enterococcus spp. (4\%), Klebsiella oxytoca (3\%), Enterobacter spp. (<3\%) и Acinetobacter spp. (<3\%) [31]. Микроорганизмы двух и более видов выделялись по разным данным у 48 и 72\% больных врожденным буллезным эпидермолизом [30, 31]. По данным H. A. Brandling-Bennett и K.D. Morel (2010), в 13,5\% случаев при посеве отделяемого из ран больных ВБЭ был получен рост трех видов бактерий, а в 7,3\% случаев - четырех и более. В среднем при посеве выделяли $1,7 \pm 1,0$ вида бактерий [30].

Отмечено, что часто раневую поверхность заселяют бактерии, устойчивые к антибиотикам [30, 32]. У 47\% пациентов с ВБЭ обнаружена колонизация поверхности эрозий и язв метициллин-резистентными золотистыми стафилококками [31]. Устойчивые к мупироцину штаммы Staphylococcus aureus обнаружены у 65\% обследованных пациентов с ВБЭ [32]. Опасность микробной колонизации эрозий и язв, особенно при их длительном существовании, состоит в повышении риска развития сепсиса, который является одной из причин смерти больных врожденным буллезным эпидермолизом [33].

У $36,7 \%$ больных ВБЭ из отделяемого из эрозий и язв были выделены культуры патогенных грибов, чаще всего это были Candida albicans или Candida parapsilosis. У пациентов с ВБЭ на поверхности эрозий и язв обнаруживался также вирус простого герпеca 1-го типа [30, 34]. По данным Н. A. Brandling-Bennett и K.D. Morel (2010), вирус простого герпеса 1-го типа был обнаружен у 6,7\%, в том числе в очагах поражения слизистой оболочки полости рта [30]. Это требует учитывать герпетическую инфекцию как возможную причину появления эрозий у больных ВБЭ [30].

Часто поражение кожи у больных врожденным буллезным эпидермолизом сопровождается болезненными ощущениями. Их возникновение ассоциировано с появлением пузырей, наличием эрозий и присоединением вторичной инфекции кожи. Деформации суставов, вызванные рубцами и контрактурами, нарушают нормальное фрункционирование суставов, что также может приводить к появлению болезненных ощущений при движениях в этих суставах [35]. Боль у больных ВБЭ может возникать в покое, во время повседневной деятельности, в том числе во время смены одежды или купания, или в результате повреждения кожи [35]. Показано, что боль различной интенсивности - от умеренно выраженной до сильной - ежедневно испытывают более 90\% пациентов с врожденным буллезным эпидермолизом [36]. Наиболее выражены болезненные ощущения при рецессивном дистрофическом ВБЭ. 
При обследовании пациентов со всеми типами ВБЭ 14-19\% из них уровень интенсивности боли оценивали в 5 и более баллов из 10 возможных, но при выделении из этой выборки больных рецессивным дистрофическим ВБЭ оказалось, что болезненные ощущения аналогичного высокого уровня интенсивности в 5 баллов и более испытывают почти 50\% пациентов. Боли не испытывали только 5\% пациентов детского возраста и 9\% взрослых пациентов с рецессивным дистрофическим ВБЭ [36].

Поражение кожи у больных любым типом ВБЭ может сопровождаться зудом, а при пруригинозной форме дистрофического типа эпидермолиза он является обязательным признаком болезни [37, 38]. Его возникновение связывается с развитием воспалительной реакции в коже и продукцией воспалительных цитокинов, нейропептидов и фракторов роста [37, 39-42]. Известно, что процессы заживления ран сопровождаются зудом $[38,42]$. Тем не менее больные ВБЭ отмечают появление зуда не только в области заживающих эрозивно-язвенных дефектов кожи, но и на видимо интактных участках [41]. В качестве фракторов, способствующих появлению зуда, 65\% больных назвали пребывание в теплом микроклимате, а 62\% - повышенное потоотделение [37].

Зуд относят к основным негативным факторам качества жизни пациентов с ВБЭ [43]. У $88 \%$ больных зуд приводил к нарушениям сна, у 85\% - к повреждениям кожи в результате расчесывания [37]. Негативное влияние зуда на состояние кожи больных ВБЭ обусловлено тем, что расчесывание представляет собой механическую травму, способствующую появлению у больных новых пузырных высыпаний, ухудшению состояния существующих дефектов кожи, увеличению риска развития вторичного инфицирования очагов поражения [35].

Длительное существование эрозивно-язвенных дефектов кожи, обусловленное неэффективностью репаративных процессов, приводит к тому, что процессы заживления находятся в состоянии постоянной активации. Постоянная активация процессов регенерации в краях длительно существующих язв, что особенно характерно для дистрофического эпидермолиза, способствует фрормированию очагов высокодифференцированного плоскоклеточного рака, который характеризуется агрессивным течением, быстрым метастазированием и часто приводит к смерти больных рецессивным дистрофическим врожденным буллезным эпидермолизом в возрасте 30-40 лет [44, 45]. Предполагается также, что фактором, повышающим риск развития плоскоклеточного рака кожи у больных ВБЭ, является микробная колонизация длительно существующих эрозивно-язвенных дефектов кожи [46].

Клинические проявления врожденного буллезного эпидермолиза определяют цели и направления наружной и местной лекарственной терапии, которая в отсутствие доступных средств патогенетической терапии является симптоматической [47]. Основными направлениями наружной и местной терапии больных врожденным буллезным эпидермолизом являются защита кожи от травмирования, ее увлажнение, стимуляция заживления эрозивно-язвенных дефектов кожи, предотвращение и борьба с инфицированием очагов поражения, устранение боли и зуда. В настоящем обзоре литературы рассматриваются современные возможности проведения наружной и местной лекарственной терапии больных врожденным буллезным эпидермолизом с уче- том информации, приведенной в инструкциях по медицинскому применению лекарственных препаратов, размещенных в Государственном реестре лекарственных средств grls.rosminzdrav.ru.

\section{Использование средств смягчающего и защитного действия}

В качестве средства первой помощи при легких повреждениях кожи пациентам с врожденным буллезным эпидермолизом могут быть рекомендованы препараты со смягчающим и защитным действием [48]. С этой целью можно использовать цинка оксид 10\% мазь для наружного применения, которую наносят тонким слоем [48]. Мазь оксида цинка наносят только на поверхностные и неинфицированные поражения, при необходимости накладывают повязку. Цинка оксид может также использоваться в форме суспензии для наружного применения. Тампоном, смоченным препаратом, наносят суспензию на пораженные участки кожи 2-3 раза в сутки. У мази и суспензии оксида цинка нет возрастных ограничений по применению.

\section{Терапия, направленная на заживление эрозий и язв}

Для стимуляции эпителизации имеющихся у больных врожденным буллезным эпидермолизом эрозивно-язвенных дефектов используются препараты для лечения ран и язв, в том числе препараты, способствующие нормальному рубцеванию (Декспантенол, цинка гиалуронат) или прочие препараты, применяемые в дерматологии (Солкосерил®, диоксометилтетрагидропиримидин (Метилурацил)).

Декспантенол считается эфрфективным средством заживления дефектов кожи при врожденном буллезном эпидермолизе [48-53]. Его используют как 5\% крем или 5\% мазь для наружного применения. Возможно его использование в форме 4,63\% аэрозоля для наружного применения. Крем или мазь декспантенола наносят тонким слоем 1-2 раза в сутки (при необходимости чаще) на пораженную поверхность и слегка втирают. Не следует наносить крем и мазь декспантенола на мокнущие поверхности. Аэрозоль применяется наружно 1 или несколько раз в сутки путем распыления с расстояния 10-20 см так, чтобы вся поврежденная поверхность была покрыта препаратом (пеной). При применении в области лица не следует разбрызгивать аэрозоль непосредственно на лицо. Нужно сначала нанести препарат на руку, чтобы затем распределить его по поврежденному участку кожи лица. Продолжительность лечения с использованием аэрозоля декспантенола зависит от тяжести заболевания. Крем, мазь и аэрозоль декспантенола могут назначаться взрослым и детям любого возраста. Применение аэрозоля у детей должно проводиться под наблюдением взрослых.

Для заживления эрозий и язв при врожденном буллезном эпидермолизе может использоваться солкосерил [49-52, 54]. Его применяют в фрорме геля или мази для наружного применения. Солкосерил наносят непосредственно на раневую поверхность после предварительного очищения раны с применением дезинфицирующего раствора. Гель для наружного применения солкосерил наносится на свежие раны, раны с влажным отделяемым, на язвы с явлениями мокнутия тонким слоем на очищенную от отделяемого поверхность 2-3 раза в сутки. Применение геля солкосерил продолжают до образования выраженной грануляционной тка- 
ни на поврежденной поверхности кожи и подсыхания раны. Мазь солкосерил используется в первую очередь для лечения сухих (немокнущих) ран. Мазью солкосерил следует смазывать участки с начавшейся эпителизацией. Ее наносят тонким слоем на очищенную рану 1-2 раза в сутки. Мазь солкосерил можно применять под повязками. Курс лечения мазью солкосерил продолжается до полного заживления раны, ее эпителизации и образования эластичной рубцовой ткани. Для назначения геля солкосерил имеется возрастное ограничение. Он противопоказан детям до 12 лет. Возрастных ограничений для назначения мази солкосерил нет, она может назначаться детям любого возраста.

В.И. Альбанова (2010) рекомендует использовать для заживления эрозий и язв у больных врожденным буллезным эпидермолизом диоксометилтетрагидропиримидин (Метилурацил) [54]. Диоксометилтетрагидропиримидин может применяться в форме 3\% или 10\% мази для местного и наружного применения (метилурациловой мази). Мазь диоксометилтетрагидропиримидина ежедневно наносят на пораженные участки тонким слоем в количестве 5-10 г в течение 15-30 дней. Перед ее нанесением рану следует обработать антисептиком и удалить остатки некротических тканей. У детей до 3 лет, при беременности и в период лактации диоксометилтетрагидропиримидин следует применять под контролем врача.

Для лечения больных врожденным эпидермолизом применяется также цинка гиалуронат [54]. Он назначается для лечения плохо заживающих инфицированных эрозий и язв и для ускорения их заживления в форме 0,205\% раствора для наружного применения [55]. После предварительного промывания поверхности раны физиологическим раствором или, при необходимости, 3\% водным раствором пероксида водорода следует нанести несколько капель раствора цинка гиалуроната на марлевую салфетку в количестве, необходимом для равномерного увлажнения всей раневой поверхности в максимальной дозе 1 капля/1 см². После этого покрывают рану стерильной марлевой салфеткой или бинтом, не липнущим к раневой поверхности. На сильно мокнущие раны раствор можно наносить 2 раза в сутки. Длительность терапии индивидуальна и зависит от формы и тяжести заболевания.

\section{Терапия, направленная на уменьшение сухости кожи и гиперкератоза}

В случаях выраженности сухости кожи больным врожденным буллезным эпидермолизом следует рекомендовать для нанесения на сухие участки кожи, в том числе после заживления эрозий, ретиноиды для местного лечения угревой сыпи (ретинол, витамин $\mathrm{E}+$ колекальциферол + ретинол (Радевит Актив) или прочие препараты, применяемые в дерматологии (диоксометилтетрагидропиримидин + ретинол) $[49,50,54,56]$.

Ретинол для устранения сухости кожи у больных врожденным буллезным эпидермолизом применяется в фрорме 0,5\% мази для наружного применения (Видестим). Ее наносят тонким слоем на пораженные участки кожи 2 раза в сутки: рано утром и поздно вечером. Перед нанесением 0,5\% мази ретинола следует обработать имеющиеся трещины, ссадины и другие дефекты кожи антисептиками. Возрастные ограничения для назначения 0,5\% мази ретинола отсутствуют, ее можно назначать в любом возрасте.
В целях уменьшения сухости кожи может также использоваться мазь для наружного применения витамин E + колекальциферол + ретинол (Радевит Актив) [49]. Эту мазь наносят на пораженные участки кожи тонким слоем 2 раза в сутки. Перед нанесением мази витамин E + колекальциферол + ретинол на трещины и другие дефекты кожи их предварительно обрабатывают антисептиками. Мазь Радевит Актив может применяться у взрослых и детей любого возраста.

Уменьшению сухости кожи также способствует мазь для наружного применения диоксометилтетрагидропиримидин + ретинол (Редецил) $[49,50,56]$. Для этого ее наносят тонким слоем на пораженные участки кожи утром и вечером в течение 4-12 недель. Возрастные ограничения для назначения мази диоксометилтетрагидропиримидин + ретинол (Редецил) отсутствуют. Она может назначаться в любом возрасте.

Кроме того, пациентам с врожденным буллезным эпидермолизом, у которых отмечается сухость кожи, рекомендуется ежедневное использование эмолиентов, что способствует также уменьшению зуда и склонности к образованию пузырей [57].

В случае формирования у больных врожденным буллезным эпидермолизом очагов гиперкератоза, в том числе в форме ладонно-подошвенной кератодермии, следует использовать кератолитические средства - мочевину или салициловую кислоту [58, 59]. При использовании этих веществ и выборе концентрации следует учитывать возраст пациента, ожидаемую частоту аппликаций, длительность лечения и локальную переносимость [59].

Мочевина в качестве кератолитического средства используется в фрорме 30\% мази для наружного применения. При поражениях кожи, сопровождающихся избыточным ороговением, мазь мочевины наносят на участки роговых наслоений тонким слоем 2 раза в сутки. Возрастные ограничения для назначения 30\% мази мочевины отсутствуют. Тем не менее А.В. Самцов и И.Э. Белоусова (2012) рекомендуют использовать для лечения больных врожденным буллезным эпидермолизом 5\% мазь с мочевиной [52]. Рекомендуется при назначении кератолитиков детям соблюдать особую осторожность [59].

Салициловая кислота может использоваться как 2\%, 5\% и 10\% мазь. Ее следует наносить на участки гиперкератоза и шелушения тонким слоем 1-2 раза в сутки. Салициловая мазь в любой концентрации назначается только взрослым, она противопоказана в детском возрасте.

\section{Терапия, направленная на уменьшение зуда}

Пациентам, предъявляющим жалобы на зуд, рекомендуются в качестве наружной терапии для уменьшения интенсивности зуда средства для лечения дерматита, кроме кортикостероидов (такролимус и пимекролимус) [60-62]. Считается также возможным использовать в составе наружной терапии для уменьшения зуда у больных врожденным буллезным эпидермолизом глюкокортикоиды [62].

Уменьшения зуда у больных врожденным буллезным эпидермолизом можно добиться применением В наружной терапии пимекролимуса [61]. Пимекролимус назначается в форме $1 \%$ крема для наружного применения. Его наносят тонким слоем на пораженную поверхность 2 раза в сутки и осторожно втирают 
до полного впитывания. Противопоказанием для назначения $1 \%$ крема для наружного применения пимекролимус является детский возраст до 3 месяцев.

Для уменьшения зуда у больных врожденным буллезным эпидермолизом может назначаться также 0,03\% мазь такролимуса. Описан случай значительного уменьшения интенсивности зуда у 53-летней пациентки с пруригинозным врожденным буллезным эпидермолизом в течение одной недели после начала наружной терапии, при этом в течение 6 месяцев использования пациенткой 0,03\% мази такролимуса не наблюдалось развития нежелательных явлений или усиления зуда [60]. Мазь для наружного применения, содержащая 0,03\% такролимуса, может назначаться взрослым и детям старше 2 лет. Ее наносят тонким слоем на пораженные участки кожи. Противопоказанием для назначения 0,03\% мази такролимуса для наружного применения является детский возраст до 2 лет.

При назначении глюкокортикоидов для уменьшения интенсивности зуда у больных врожденным буллезным эпидермолизом следует проводить лечение короткими курсами [62]. Имеются данные об использовании в наружном лечении больных врожденным буллезным эпидермолизом лекарственных препаратов, содержащих 0,1\% или $1 \%$ гидрокортизона $[61,63]$. Лекарственные препараты, содержащие гидрокортизон в концентрации 0,1\%, могут использоваться в фрорме крема, мази или эмульсии для наружного применения. Их наносят тонким слоем на пораженные участки кожи не чаще 2 раз в сутки в течение 2-4 недель. Применение 0,1\% крема, мази и эмульсии гидрокортизона возможно с 6-месячного возраста. Противопоказанием к их назначению является детский возраст до 6 месяцев. Гидрокортизоновую мазь 1\% для наружного применения рекомендуют взрослым и детям старше 2 лет наносить на пораженные участки кожи тонким слоем 1-3 раза в сутки в течение 2-4 недель. Противопоказанием к назначению $1 \%$ мази гидрокортизона является детский возраст до 2 лет. Следует учитывать, что при длительном курсе наружной кортикостероидной терапии у больных возможно как быстрое развитие атрофии кожи и вторичного инфицирования, так и возникновение тяжелых системных побочных эфрфектов [62].

Кроме того, Н.Н. Мурашкин, Л.С. НамазоваБаранова указывают на возможность использования для уменьшения зуда у больных врожденным буллезным эпидермолизом камфоры и средств, содержащих ментол в концентрации до $2 \%$ [62].

\section{Терапия, направленная на предупреждение и устранение вторичной инфекции}

В связи с тем, что эрозии и язвы больных врожденным буллезным эпидермолизом быстро колонизируются различными микроорганизмами, для предупреждения развития клинически значимого инфекционного поражения необходимо перед перевязками эти дефекты кожи обрабатывать антисептиками и дезинфицирующими средствами. Возможно использование с этой целью метилтиониния хлорида. Растворы антисептиков и дезинсрицирующих средств используются также для обработки пузырей перед их вскрытием. После вскрытия пузыри затем повторно обрабатывают раствором препарата из группы антисептиков и дезинфицирующих средств. Использование этих препаратов также необходимо в случаях клинически проявляющегося инфекционного поражения кожи.
Кожа больных врожденным буллезным эпидермолизом отличается повышенной чувствительностью и проницаемостью, и с учетом того, что обработке может подвергаться значительная площадь поверхности кожного покрова, следует отдавать предпочтение водным растворам антисептиков и дезинфицирующих средств перед спиртовыми.

Для обработки пузырей и эрозивно-язвенных поверхностей может использоваться хлоргексидин $[49,50]$. Используют его 0,02\%, 0,05\%, 0,2\%, 0,5\% водные растворы для наружного и местного применения в виде орошений, полосканий и аппликаций. На пораженную поверхность кожи или слизистых оболочек наносят 5-10 мл раствора с экспозицией 1-3 минуты 2-3 раза в сутки (на тампоне или путем орошения). В детском возрасте хлоргексидин следует применять с осторожностью.

Возможно использование для обработки пузырей, эрозий и язв гидроксиметилхиноксалиндиоксида [49, $53,54]$. Он назначается в форме раствора для местного и наружного применения или в фрорме 5\% мази для наружного применения. Для лечения поверхностных инфицированных гнойных ран на рану накладывают салфетки, смоченные 0,5-1\% раствором гидроксиметилхиноксалиндиоксида. Глубокие раны после обработки рыхло заполняют тампонами, смоченными $1 \%$ раствором препарата, а при наличии дренажной трубки в полость вводят от 20 до 100 мл 0,5\% раствора препарата. Для получения раствора нужной концентрации разводят ампульные растворы препарата, используя растворитель для приготовления лекарственных форм для инъекций натрия хлорид (стерильный 0,9\% раствор) или воду для инъекций. Мазь гидроксиметилхиноксалиндиоксида накладывают тонким слоем непосредственно на пораженный участок, предварительно очищенный от гнойно-некротических масс. Гидроксиметилхиноксалиндиоксид назначается только взрослым. Противопоказанием для использования препарата и в фрорме раствора, и в фрорме мази является детский возраст (до 18 лет).

Бензилдиметил-миристоиламино-пропиламмоний (Мирамистин) также может использоваться для обработки поражений кожи у больных врожденным буллезным эпидермолизом $[49,54]$. Он назначается в фрорме $0,01 \%$ раствора для местного применения. Этим раствором орошают поверхность ран, рыхло тампонируют раны и свищевые ходы, фриксируют марлевые тампоны, смоченные препаратом. Лечебная процедура повторяется 2-3 раза в сутки в течение 3-5 дней. Высокоэфрективен метод активного дренирования ран и полостей с суточным расходом до 1 л препарата. При стоматитах, гингивитах, пародонтитах проводится полоскание ротовой полости 10-15 мл препарата 3-4 раза в сутки. Не рекомендуется применение препарата в форме спрея для орошения горла и миндалин детям в возрасте до 3 лет ввиду риска развития реактивного ларингоспазма.

При врожденном буллезном эпидермолизе может назначаться нитрофрурал $[49,50]$. Нитрофрурал в форме 0,02\% раствора для местного и наружного применения может использоваться путем орошения гнойных ран и мелких повреждений кожи. Он может использоваться в любом возрасте, так как не имеет ограничений по возрасту для своего использования.

Рекомендовано использование для обработки пораженной кожи больных врожденным буллезным эпидермолизом раствора для местного и наружного при- 
менения октенидина дигидрохлорид + френоксиэтанол (спрей МестаМидин-сенс) [49]. Он используется путем орошения кожи и слизистых оболочек. Пораженная поверхность должна быть обработана полностью. Время экспозиции - не менее 1-2 минут. Препарат может использоваться в любом возрасте. Для обработки кожи новорожденных препарат применяется в неразбавленном виде методом орошения или методом протирания с помощью тампона, обильно смоченного препаратом, 2 раза в сутки в течение 5-7 дней.

При необходимости обработки эрозий и язв у больных врожденным буллезным эпидермолизом в качестве антисептического средства может быть использован раствор для наружного применения октенисепт [50]. Препарат может использоваться наружно и местно. Пораженный участок поочередно обрабатывают двумя тампонами, обильно смоченными раствором октенисепт. На легко доступные участки препарат может быть нанесен путем распыления. Октенисепт используется у взрослых и в детской практике без возрастных ограничений.

В качестве антисептического средства также можно использовать комбинированный препарат борная кислота + резорцин + френол + фуксин (Фукорцин) [50]. Раствор фукорцин наносят наружно с помощью ватного тампона на пораженные участки кожи 2-4 раза в сутки. Для назначения фукорцина отсутствуют ограничения по возрасту, его можно применять у взрослых и детей любого возраста. Тем не менее следует учитывать, что раствор фукорцин содержит этиловый спирт и может плохо переноситься больными врожденным буллезным эпидермолизом.

Считается возможным использовать в наружной терапии больных врожденным буллезным эпидермолизом раствор для наружного применения бриллиантового зеленого [50]. 1\% спиртовой раствор бриллиантового зеленого наносят непосредственно на пораженную поверхность с захватом окружающих тканей. Ограничений по возрасту для применения этого препарата нет, за исключением необходимости соблюдения осторожности при использовании в детском возрасте до 3 лет. Однако содержание этилового спирта в его составе может ухудшить переносимость раствора бриллиантового зеленого пациентами с врожденным буллезным эпидермолизом.

Указано на возможность использования для обработки поражений кожи при врожденном буллезном эпидермолизе метилтиониния хлорида (метиленового синего) $[49,50,54]$. Он применяется как $1 \%$ раствор для местного и наружного применения (водный) на пораженные участки 2-3 раза в сутки. Ограничений по возрасту для применения метилтиониния хлорида нет. Взрослым и детям с момента рождения раствор метилтиониния хлорида наносят на пораженную поверхность с помощью тампона или стеклянной палочки.

В случаях развития вторичного инфицирования, клиническими признаками которого могут быть гнойное отделяемое и гнойные корки, вместе с антисептиками и дезинфицирующими средствами в комплекс наружной терапии должны быть включены антибиотики и противомикробные средства, применяемые в дерматологии (мупироцин, фузидовая кислота, гентамицин, линкамицин, бацитрацин + неомицин, сульфратиазол серебра, сульфадиазин), или препараты для лечения угревой сыпи местного применения (эритромицин) [49, $50,54,56,59,64,65]$.
Для устранения инфицирования кожных покровов у больных врожденным буллезным эпидермолизом может использоваться мупироцин $2 \%$ мазь для наружного применения [49, 50, 54, 59, 65]. Небольшое количество мази мупироцина наносят на пораженную поверхность кожи 2-3 раза в сутки с помощью ватного или марлевого тампона, инфицированные очаги поражения кожи 3 раза в сутки в течение 7 дней. Затем на область нанесения мази может быть наложен стерильный бандаж или марлевая повязка. Частота нанесения и длительность лечения мазью мупироцина зависит от динамики клинической картины. Этот препарат не следует применять более 10 дней. Нет ограничений по применению мази мупироцина у детей, в связи с чем она может назначаться в любом возрасте.

Эфффективным средством терапии инфекционных поражений кожи при врожденном буллезным эпидермолизе считается фузидовая кислота [49, 54, 56]. Фузидовая кислота может назначаться в форме 2\% крема или $2 \%$ мази для наружного применения. Ее следует наносить на пораженные участки кожи тонким слоем 3-4 раза в сутки. При использовании марлевых повязок частота нанесения может быть уменьшена до 1-2 раз в сутки. Продолжительность лечения зависит от фрормы и тяжести заболевания и в среднем составляет 7-14 дней. Крем и мазь фузидовой кислоты используют у взрослых и детей с рождения.

В случаях осложнения врожденного буллезного эпидермолиза инфекционными поражениями кожи для наружной терапии может также назначаться гентамицин $[49,54]$. Он применяется в форме 0,1\% мази для наружного применения. Мазь, содержащую гентамицин, тонким слоем наносят на пораженный участок 3-4 раза в сутки. Курс лечения обычно составляет 7-14 дней. Длительность лечения устанавливается врачом. При необходимости накладывают повязку. Ограничений для применения 0,1\% мази гентамицина по возрасту нет. Ее можно использовать в любом возрасте, но в период новорожденности и у недоношенных детей ее следует применять с осторожностью.

В состав наружной терапии больных врожденным буллезным эпидермолизом при развитии явлений пиодермии (гнойное отделяемое, гнойные корки) можно включать линкомицин [49, 54]. Линкомицин применяется для наружной терапии в фрорме $2 \%$ мази для наружного применения. Ее наносят тонким слоем на кожу в месте очага поражения 2-3 раза в сутки взрослым и детям старше 1 месяца. Новорожденным (до 1 месяца) $2 \%$ мазь линкомицина противопоказана.

Как эфффективное средство терапии в случае вторичного инфицирования очагов поражения у больных врожденным буллезным эпидермолизом рассматривается мазь для наружного применения бацитрацин + неомицин $[49,50,54,64]$. Ее наносят тонким слоем на пораженные участки 2-3 раза в сутки, если это целесообразно - под повязку. Однако мазь бацитрацин + неомицин не следует использовать при обширных поражениях кожи, поскольку всасывание препарата может вызвать ототоксический эффрект, сопровождающийся потерей слуха. Назначать мазь бацитрацин + неомицин можно взрослым и детям любого возраста.

K препаратам наружной терапии, эффрективным при вторичном инфрицировании очагов поражения при врожденном буллезном эпидермолизе, относят 
сульфратиазол серебра $[49,54]$. Сульфратиазол серебра $2 \%$ крем для наружного применения используется как открытым методом, так и под окклюзионные повязки. Препарат наносят на рану с соблюдением условий стерильности и толщиной 2-3 мм 2-3 раза в сутки после очищения и хирургической обработки. Рана во время лечения должна быть вся покрыта кремом. Если часть раны откроется, необходимо дополнительно нанести крем. Перед применением крема сульфратиазола серебра следует промыть рану $0,1 \%$ водным раствором хлоргексидина или другим антисептиком. В случае применения препарата на инфицированные раны может появиться экссудат. Противопоказанием к применению $2 \%$ крема сульфатиазола серебра является грудной возраст до 2 месяцев из-за риска развития «ядерной» желтухи.

Для терапии больных врожденным буллезным эпидермолизом, у которых выявлено вторичное инсрицирование очагов поражения, могут также использоваться сульсрадиазин и сульфадиазин серебра [49, 54]. После хирургической обработки раневой поверхности сульфадиазин 1\% крем или 1\% мазь для наружного применения наносится на нее слоем толщиной 2-4 мм 1-2 раза в сутки. $1 \%$ крем сульфадиазина можно использовать с применением повязок или без них. 1\% мазь сульфадиазина не следует применять для лечения глубоких гнойных ран с обильной экссудацией. Применение 1\% крема сульфадиазина противопоказано недоношенным новорожденным, а также детям в течение первых 2-х месяцев после рождения. Противопоказанием для применения 1\% мази сульфадиазина является детский возраст до 1 года.

Сульфадиазин серебра в форме 1\% крема для наружного применения следует наносить взрослым и детям старше 2 лет на пораженную поверхность после очистки раны слоем толщиной 2 мм 2 раза в сутки. Сульфадиазин серебра противопоказан в детском возрасте до 2 лет.

Во время наблюдения за больными врожденным буллезным эпидермолизом возможны ситуации, когда необходимо использование лекарственных препаратов, одновременно стимулирующих заживление эрозий и язв и устраняющих признаки вторичного инфицирования. В таких случаях можно рекомендовать лекарственные препараты, в состав которых входят вещества, обладающие антимикробным и ранозаживляющим действием, например, диоксометилтетрагидропиримидин + хлорамфреникол (Левомеколь), диоксометилтетрагидропиримидин + сульфадиметоксин + тримекаин + хлорамфеникол (Левосин) или мазь Фузимет [50, 53, 66].

А.А. Афронин и соавт. (2016) сообщают об использовании мази Левомеколь в лечении больного врожденным буллезным эпидермолизом [53]. Мазью для наружного применения диоксометилтетрагидропиримидин + хлорамфреникол 40 мг/г + 7,5 мг/г пропитывают стерильные марлевые салфетки, которыми рыхло заполняют рану. Перевязки производят ежедневно, 1 раз в день, до полного очищения раны от гнойнонекротических масс. Возможно введение препарата В гнойные полости через катетер (дренажную трубку) с помощью шприца. В таком случае мазь предварительно подогревают до $35-36^{\circ} \mathrm{C}$. При больших раневых поверхностях суточная доза мази в пересчете на хлорамфеникол не должна превышать 3 г. Длительность лечения зависит от тяжести и течения заболевания. Противопоказанием к назначению мази для наружного применения диоксометилтетрагидропиримидин + хлорамфеникол является детский возраст до 1 года.
Мазь для наружного применения диоксометилтетрагидропиримидин + сульфрадиметоксин + тримекаин + хлорамфеникол также используется путем пропитывания стерильных марлевых салфеток, которыми затем рыхло заполняют рану. Перевязки производят ежедневно, 1 раз в день, до полного очищения раны от гнойно-некротических масс. При больших раневых поверхностях суточная доза мази в пересчете на хлорамфеникол не должна превышать у взрослых 3 г, у детей от 4 недель и старше доза не должна превышать 50 мг/кг массы тела, учитывая, что в 1 см выдавленной из тубы мази содержится 1,12 мг хлорамфеникола. В детском возрасте от 4 недель до 1 года препарат следует применять с осторожностью.

В лечении больных врожденным буллезным эпидермолизом может использоваться мазь Фузимет [50]. Она содержит в своем составе фрузидовую кислоту, оказывающую антимикробное действие, и стимулятор клеточной регенерации диоксометилтетрагидропиримидин (метилурацил). Ее наносят тонким слоем 1-2 раза в сутки на пораженную поверхность после удаления гноя и некротических масс. Поскольку в число противопоказаний к назначению мази Фузимет входит детский возраст до 18 лет, она может назначаться только взрослым.

Удобством и равномерностью нанесения лекарственного средства на раневую поверхность отличаются средства в аэрозольной упаковке. В связи с этим для наружного лечения больных врожденным буллезным эпидермолизом, у которых развилось инфекционное поражение в области эрозий и язв, рекомендуется использовать аэрозоль для местного применения диоксометилтетрагидропиримидин + облепиховое масло + сульфаэтидол (Гипозоль), содержащий в своем составе как антисептик, так и средство регенерирующего действия [52, 54]. После очищения эрозивно-язвенных поверхностей от экссудата и некротических тканей на них наносят пену препарата равномерным слоем толщиной 1-1,5 см 1-2 раза в сутки. При лечении ран небольшого размера препарат можно нанести на стерильную салфетку и таким образом закрыть раневую поверхность. При заболеваниях слизистой оболочки полости рта и пародонта пеной покрывают пораженный участок на 10-15 минут от 3 до 5 раз в сутки, курс лечения 1-2 недели. Продолжительность лечения определяется скоростью эпителизации ран. В детском возрасте до 18 лет препарат следует применять с осторожностью.

При необходимости уменьшения болезненных ощущений в области инфицированных эрозий и язв у больных врожденным буллезным эпидермолизом показаны другие антисептики и дезинфицирующие средства, содержащие местные анестетики. С этой целью может использоваться аэрозоль для местного применения бензокаин + борная кислота + облепихи масло + хлорамфеникол (Олазоль) [50, 52, 54, 63]. За счет содержания в своем составе бензокаина он оказывает анестезирующее действие. Этот лекарственный препарат наносят на раневую поверхность, очищенную по возможности от гноя и некротических тканей, покрывая ее равномерно тонким слоем пены ежедневно или через день, а при открытом лечении ран - 1-4 раза в сутки в зависимости от характера воспаления и стадии регенерации поврежденных тканей. Курс лечения определяется индивидуально лечащим врачом. Для по- 
лучения равномерного слоя пены баллон необходимо встряхнуть (10-15 раз). Пену наносят до покрытия всей раневой поверхности с расстояния $1-5 \mathrm{~cm}$. В раннем детском возрасте этот препарат следует использовать с осторожностью.

\section{Средства для терапии поражений полости рта}

Поражение слизистой оболочки полости рта у больных врожденным буллезным эпидермолизом, как и поражение кожи, характеризуется развитием воспаления и сопровождается болезненными ощущениями. В связи с этим при поражениях полости рта пациентам необходима местная терапия средствами, оказывающими местноанестезирующее, противовоспалительное и антисептическое действие. Уменьшения интенсивности боли можно также добиться местным применением противовоспалительных средств за счет уменьшения выраженности воспаления.

В случае выраженной или труднопереносимой боли следует использовать в терапии препараты для лечения заболеваний полости рта, содержащие вещества, обладающие местноанестезирующим действием.

Местноанестезирущим, противовоспалительным и антисептическим эффектом обладает гель стоматологический холина салицилат + цеталкония хлорид (Холисал). Его использование рекомендуется при врожденном буллезном эпидермолизе [67, 68]. Холисал применяют 2-3 раза в день до еды (с целью обезболивания) или после еды и перед сном. Полоску геля длиной 1 см для взрослых и 0,5 см для детей выдавливают на чистый палец и втирают легкими массирующими движениями в пораженный участок слизистой оболочки полости рта. Препарат противопоказан в детском возрасте до 1 года.

Н.В. Бенова и соавт. (2013) рекомендуют при поражениях слизистой оболочки полости рта гель для местного применения лидокаин + ромашки аптечной цветков экстракт (Камистад) [67]. Он оказывает местноанестезирующее и антисептическое действие. Используют его, нанося полоску препарата длиной 0,5 см на болезненные или воспаленные участки слизистой оболочки полости рта и губ 3 раза в сутки, втирая легкими массирующим движениями. Противопоказанием для назначения Камистада является детский возраст до 12 лет.

Гель стоматологический Дентинокс показан для уменьшения боли при прорезывании зубов у детей, в том числе больных врожденным буллезным эпидермолизом [67]. Он является местноанестезирующим и противовоспалительным средством. При первых признаках прорезывания зубов следует нанести чистым пальцем или ватной палочкой небольшое количество геля, величиной с горошину, на десну в месте прорезывания зуба, легко втереть. Процедуру повторять 2-3 раза в сутки после еды и перед сном. При необходимости можно использовать препарат в течение всего периода молочных и постоянных зубов. С этой же целью уменьшения боли при прорезывании зубов может быть использован гель для местного применения лидокаин + ромашки аптечной цветков экстракт (Камистад) [67].

Уменьшение интенсивности болезненных ощущений возможно при использовании лекарственных средств, обладающих противовоспалительным эффектом. Эти средства могут применяться в случае выявления воспалительного поражения слизистой оболочки полости рта.
Предложено использовать для лечения поражений полости рта у больных врожденным буллезным эпидермолизом шалфея лекарственного листья [49]. Этот средство назначается в форме листьев порошка. Настой листьев шалфея оказывает противомикробное, противовоспалительное и вяжущее действие. Три фильтр-пакета (4,5 г) помещают в стеклянную или эмалированную посуду, заливают 100 мл (1/2 стакана) кипятка, накрывают и настаивают 15 минут, периодически надавливая на пакетики ложкой, затем их отжимают. Объем полученного настоя доводят кипяченой водой до 100 мл. Применяют местно для полосканий у взрослых и детей старше 12 лет по 1/2 стакана настоя 3-5 раз в сутки в теплом виде. Курс лечения - 1 неделя. Перед применением настой следует взболтать. Противопоказанием является детский возраст до 12 лет.

Ромашки аптечной цветки - цветки измельченные [49]. Настой из цветков ромашки оказывает противовоспалительное и умеренное противомикробное действие. Около 9 г (2 столовые ложки) цветков ромашки помещают в эмалированную посуду, заливают 200 мл (1 стакан) горячей кипяченой воды, закрывают крышкой, нагревают на кипящей водяной бане при периодическом помешивании 15 минут, охлаждают при комнатной температуре 45 минут, процеживают, оставшееся сырье отжимают. Объем полученного настоя доводят кипяченой водой до 200 мл. Местно для полосканий полости рта применяют по $1 \frac{2}{2}-1$ стакану теплого настоя 3-5 раз в день. Ограничений по возрасту нет, может применяться в любом возрасте у детей и взрослых.

При поражении полости рта у больных врожденным буллезным эпидермолизом могут также использоваться противомикробные препараты и антисептики для местного лечения заболеваний полости рта, к которым относятся гель стоматологический метронидазол + хлоргексидин 1\% + 0,05\% и раствор для местного применения и приема внутрь Ромазулан $[49,68]$.

Гель стоматологический метронидазол + хлоргексидин 1\% + 0,05\% при воспалении десен (гингивите) наносится на область десен 2 раза в сутки, смывать гель не рекомендуется. Длительность курса лечения составляет в среднем 7-10 дней. После нанесения геля следует воздержаться от приема пищи в течение 30 минут. При язвах полости рта препарат наносится на пораженную область слизистой оболочки полости рта 2 раза в сутки в течение 7-10 дней. Противопоказанием является детский возраст до 6 лет.

Раствор для местного применения и приема внутрь Ромазулан оказывает противовоспалительное и некоторое противомикробное действие. Ромазулан в разведенном виде ( $1 / 2$ столовой ложки на 1 литр воды) может применяться наружно в виде повязок, промываний и компрессов и местно в виде клизм, полосканий, влагалищных спринцеваний. Ограничений для местного и наружного применения ромазулана по возрасту нет, он может применяться в любом возрасте.

Возможно использование в терапии поражения полости рта у больных врожденным буллезным эпидермолизом раствора хлоргексидина. Полосканием или орошением рта раствором хлоргексидина предотвращается образование зубного налета [54]. Раствор хлоргексидина применяется также для предупреждения инфицирования эрозий во рту [49]. Хлоргексидин используется в форме 0,05\% раствора для полоскания или 0,05\% спрея для местного и наружного применения. 
Готовым раствором проводят полоскание полости рта 2-3 раза в сутки. Длительность лечения определяется врачом. В детском возрасте хлоргексидин следует применять с осторожностью.

Для стимуляции заживления эрозивно-язвенных очагов поражения полости рта может использоваться Солкосерил® дентальная адгезивная паста, которая представляет собой пасту для местного применения [52]. Препарат ускоряет и качественно улучшает процессы заживления повреждений. Используют Солкосерил® дентальную адгезивную пасту путем нанесения полоски пасты длиной 0,5 см тонким слоем на поврежденный участок 3-5 раз в сутки, предпочтительно после еды и перед сном. Противопоказанием является детский возраст до 2 лет.

\section{Заключение}

Несмотря на проведение исследований по разработке новых патогенетических методов терапии врожденного буллезного эпидермолиза, в настоящее время возможно использование средств только симптоматической терапии [69]. Поскольку пациентам назначается симптоматическая терапия, следует ожидать от нее не более чем временного эфффекта. В соответствии с клиническими проявлениями заболевания в состав наружной и местной терапии больных врожденным буллезным эпидермолизом включаются лекарственные препараты, обладающие регенерирующим, анестезирующим и противозудным действием. Несмотря на то что врожденный буллезный эпидермолиз не является инфекционным заболеванием, колонизация эрозивно-язвенных поверхностей разнообразными микроорганизмами требует проведения терапии антисептическими и противомикробными средствами. Это обусловлено возможностью развития у этих пациентов сепсиса, который является ведущей причиной детской смертности у пациентов с различными подтипами ВБЭ, и до 24\% пациентов с ВБЭ умирают от сепсиса в течение первых 15 лет жизни [33]. Для оптимального выбора антибактериального препарата в таких случаях требуется микробиологическое (культуральное) исследование отделяемого высыпных элементов кожи на чувствительность к антибактериальным и противогрибковым препаратам. Тактика терапии должна быть изменена при появлении признаков развития в пределах длительно существующих эрозий, язв и рубцов плоскоклеточного рака кожи, например, усиления болей или появления новых, ранее не испытывавшихся больным ощущений, внезапного роста эрозивно-язвенного очага поражения в размерах и в глубину [71-73]. В таком случае пациентам необходима консультация врача-онколога. Пациентам с поражением слизистых оболочек может потребоваться консультация врача-стоматолога, врача-оториноларинголога, врачауролога, врача акушера-гинеколога, врача-проктолога. При врожденном буллезном эпидермолизе возможно также развитие поражения органа зрения, и тогда необходима консультация врача-офртальмолога [74]

Значительная часть больных врожденным буллезным эпидермолизом - дети [75]. Отмечено, что любой тип врожденного буллезного эпидермолиза может манифрестировать даже у новорожденного ребенка [76]. В связи с этим при выборе лекарственной терапии необходимо учитывать возраст пациента, сопоставляя его с возрастными противопоказаниями к назначению лекарственных препаратов. Повышенная чувствительность и проницаемость кожи больных врожденным буллезным эпидермолизом требует выбирать для наружной терапии в первую очередь не содержащие этиловый спирт препараты. Например, при выборе между водным и спиртовым раствором лекарственного препарата предпочтение следует отдавать водному раствору, хотя спиртовые растворы также могут использоваться в лечении больных врожденным буллезным эпидермолизом, например для нанесения на ограниченные поверхностные дефекты кожи. Принимая во внимание отсутствие резистентности кожи больных к механическим воздействиям, лекарственная терапия должна сопровождаться использованием специальных неадгезивных перевязочных средств [47, 77].

Учитывая генетический характер врожденного буллезного эпидермолиза, проводимая симптоматическая терапия может уменьшить выраженность проявлений болезни, облегчить состояние болезни. Тем не менее отсутствие возможности в настоящее время устранить генетический дефект предполагает необходимость пожизненного проведения симптоматической терапии больных.

\section{Литература/References}

1. Has C, Bauer JW, Bodemer C, Bolling MC, Bruckner-Tuderman L, Diem $A$, et al. Consensus reclassification of inherited epidermolysis bullosa and other disorders with skin fragility. 2020;183(4):614-627.

doi: 10.1111/bjd.18921

2. Coulombe PA, Kerns ML, Fuchs E. Epidermolysis bullosa simplex: a paradigm for disorders of tissue fragility. J Clin Invest. 2009;119(7):17841793. doi: $10.1172 / \mathrm{JCl} 38177$

3. Khani $P$, Ghazi $F$, Zekri A, Nasri $F$, Behrangi E, Aghdam AM, et al. Keratins and epidermolysis bullosa simplex. J Cell Physiol. 2018;234(1):289-297. doi: 10.1002/jcp.26898

4. Lin Z, Li S, Feng C, Yang S, Wang H, Ma D, et al. Stabilizing mutations of KLHL24 ubiquitin ligase cause loss of keratin 14 and human skin fragility. Nat Genet. 2016;48(12):1508-1516. doi: 10.1038/ng.3701
5. He Y, Maier K, Leppert J, Hausser I, Schwieger-Briel A, Weibel $L$, et al. Monoallelic mutations in the translation initiation codon of KLHL24 cause skin fragility. Am J Hum Genet. 2016;99(6):1395-1404. doi: 10.1016/j.ajhg.2016.11.005

6. Vahidnezhad H, Youssefian L, Saeidian AH, Mahmoudi H, Touati A, Abiri M, et al. Recessive mutation in tetraspanin CD151 causes Kindler syndrome-like epidermolysis bullosa with multi-systemic manifestations including nephropathy. Matrix Biol J Int Soc Matrix Biol. 2018;66:22-33. doi: 10.1016/j.matbio.2017.11.003

7. Jonkman MF, Pas HH, Nijenhuis M, Kloosterhuis G, Steege G. Deletion of a cytoplasmic domain of integrin beta4 causes epidermolysis bullosa simplex. J Invest Dermatol. 2002;119(6):1275-1281. doi: 10.1046/j.1523-1747.2002.19609.x 
8. Varki R, Sadowski S, Pfendner E, Uitto J. Epidermolysis bullosa. I. Molecular genetics of the junctional and hemidesmosomal variants. J Med Genet. 2006;43(8):641-652. doi: 10.1136/jmg.2005.039685

9. Mariath LM, Santin JT, Schuler-Faccini L, Kiszewski AE. Inherited epidermolysis bullosa: update on the clinical and genetic aspects. An Bras Dermatol. 2020;95(5):551-569. doi: 10.1016/j.abd.2020.05.001

10. Rognoni E, Ruppert R, Fässler R. The kindlin family: functions, signaling properties and implications for human disease. J Cell Sci. 2016;129(1):17-27. doi: 10.1242/jcs.161190

11. Fine JD, Bruckner-Tuderman L, Eady RA, Bauer EA, Bauer JW, Has $C$, et al. Inherited epidermolysis bullosa: updated recommendations on diagnosis and classification. J Am Acad Dermatol. 2014;70(6):1103-1126. doi: 10.1016/j.jaad.2014.01.903

12. Hon KL, Li JJ, Cheng BL, Luk DC, Murrell DF, Choi PC, et al. Age and etiology of childhood epidermolysis bullosa mortality. J Dermatolog Treat. 2015;26(2):178-182. doi: 10.3109/09546634.2014.915002

13. Feinstein JA, Jambal $P$, Peoples K, Lucky AW, Khuu $P$, Tang JY, et al. Assessment of the timing of milestone clinical events in patients with epidermolysis bullosa from North America. JAMA Dermatol. 2019;155(2):196-203. doi: 10.1001/jamadermatol.2018.4673

14. Tang JY, Marinkovich MP, Lucas E, Gorell E, Chiou A, Lu Y, et al. A systematic literature review of the disease burden in patients with recessive dystrophic epidermolysis bullosa. Orphanet $J$ Rare Dis. 2021;16(1):175. doi: 10.1186/s13023-021-01811-7

15. Mariath LM, Santin JT, Frantz JA, Doriqui MJR, Schuler-Faccini L, Kiszewski AE. Genotype-phenotype correlations on epidermolysis bullosa with congenital absence of skin: A comprehensive review. Clin Genet. 2021;99(1):29-41. doi: 10.1111/cge.13792

16. Tasanen K, Tunggal L, Chometon G, Bruckner-Tuderman L, Aumailley M. Keratinocytes from patients lacking collagen XVII display a migratory phenotype. Am J Pathol.2004;164(6):2027-2038.

doi: 10.1016/S0002-9440(10)63762-5

17. Van Agtmael T, Bruckner-Tuderman L. Basement membranes and human disease. Cell Tissue Res. 2010;339(1):167-188.

doi: 10.1007/s00441-009-0866-y

18. Woodley DT, Hou Y, Martin S, Li W, Chen M. Characterization of molecular mechanisms underlying mutations in dystrophic epidermolysis bullosa using site-directed mutagenesis. J Biol Chem. 2008;283(26):1783817845. doi: $10.1074 /$ jbc.M709452200

19. Rousselle P, Montmasson M, Garnier C. Extracellular matrix contribution to skin wound re-epithelialization. Matrix Biol. 2019;75-76:1226. doi: 10.1016/j.matbio.2018.01.002

20. Кубанов А.А., Карамова А.Э., Альбанова В.И., Чикин В.В., Мончаковская Е.С. Врожденный буллезный эпидермолиз: особенности регенерации эпидермиса и методы терапии. Вестник дерматологии и венерологии 2017; (4): 28-37 [Kubanov AA, Karamova AE, Al'banova VI, Chikin VV, Monchakovskaya ES. Congenital epidermolysis bullosa: peculiarities of epidermis regeneration and methods of treatment. Vestnik Dermatologii i Venerologii 2017;4:28-37 (In Russ.)].

21. Efron PA, Moldawer LL. Cytokines and wound healing: the role of cytokine and anticytokine therapy in the repair response. J Burn Care Rehabil. 2004;25(2):149-160. doi: 10.1097/01.bcr.0000111766.97335.34

22. Yoneda K, Furukawa T, Zheng YJ, Momoi T, Izawa I, Inagaki M, et al. An autocrine/paracrine loop linking keratin 14 aggregates to tumor necrosis factor alpha-mediated cytotoxicity in a keratinocyte model of epidermolysis bullosa simplex. J Biol Chem. 2004;279(8):7296-7303. doi: 10.1074/jbc.M307242200

23. Lu H, Chen J, Planko L, Zigrino P, Klein-Hitpass L, Magin TM. Induction of inflammatory cytokines by a keratin mutation and their repression by a small molecule in a mouse model for EBS. J Invest Dermatol. 2007;127(12):2781-2789. doi: 10.1038/sj.jid.5700918

24. Wally V, Lettner T, Peking P, Peckl-Schmid D, Murauer EM, Hainzl S, et al. The pathogenetic role of IL-1beta in severe epidermolysis bullosa simplex. J Invest Dermatol. 2013;133(7):1901-1903. doi: 10.1038/jid.2013.31
25. Boniface K, Blom B, Liu YJ, de Waal Malefyt R. From interleukin-23 to T-helper 17 cells: human T-helper cell differentiation revisited. Immunol Rev. 2008;226:132-146. doi: 10.1111/j.1600-065X.2008.00714.x

26. Castela $E$, Tulic MK, Rozières A, Bourrat $E$, Nicolas JF, Kanitakis J, et al. Epidermolysis bullosa simplex generalized severe induces a $\mathrm{T}$ helper 17 response and is improved by apremilast treatment. $\mathrm{Br} \mathrm{J}$ Dermatol. 2019;180(2):357-364. doi: 10.1111/bjd.16897

27. Heinemann A, He Y, Zimina E, Boerries M, Busch H, Chmel N, et al. Induction of phenotype modifying cytokines by FERMT1 mutations. Hum Mutat. 2011;32(4):397-406. doi: 10.1002/humu.21449

28. Breitenbach JS, Rinnerthaler M, Trost A, Weber M, Klausegger A, Gruber $C$, et al. Transcriptome and ultrastructural changes in dystrophic Epidermolysis bullosa resemble skin aging. Aging (Albany NY). 2015;7(6):389-411. doi: 10.18632/aging.100755

29. Has C, Nyström A, Saeidian AH, Bruckner-Tuderman L, Uitto J. Epidermolysis bullosa: Molecular pathology of connective tissue components in the cutaneous basement membrane zone. Matrix Biol. 2018;71-72:313-329. doi: 10.1016/j.matbio.2018.04.001

30. Brandling-Bennett HA, Morel KD. Common wound colonizers in patients with epidermolysis bullosa. Pediatr Dermatol. 2010;27(1):25-28. doi: 10.1111/j.1525-1470.2009.01070.x

31. Levin LE, Shayegan LH, Lucky AW, Hook KP, Bruckner AL, Feinstein JA, et al. Characterization of wound microbes in epidermolysis bullosa: Results from the epidermolysis bullosa clinical characterization and outcomes database. Pediatr Dermatol. 2021;38(1):119-124. doi: 10.1111/pde.14444

32. Singer HM, Levin LE, Garzon MC, Lauren CT, Planet PJ, Kittler NW, et al. Wound culture isolated antibiograms and caregiverreported skin care practices in children with epidermolysis bullosa. Pediatr Dermatol. 2018;35(1):92-96. doi: 10.1111/pde.13331

33. Fine JD, Johnson LB, Weiner M, Suchindran C. Cause-specific risks of childhood death in inherited epidermolysis bullosa. J Pediatr. 2008;152(2):276-280. doi: 10.1016/j.jpeds.2007.06.039.

34. Rubin Al, Garzon MC, Morel KD. Herpetic infection in epidermolysis bullosa. Pediatr Dermatol. 2006;23(4):355-357.

doi: 10.1111/j.1525-1470.2006.00254.x

35. Goldschneider KR, Lucky AW. Pain management in epidermolysis bullosa. Dermatol Clin. 2010;28(2):273-282, ix. doi: 10.1016/j.det.2010.01.008.

36. Fine JD, Johnson LB, Weiner M, Suchindran C. Assessment of mobility, activities and pain in different subtypes of epidermolysis bullosa. Clin Exp Dermatol. 2004;29(2):122-127. doi: 10.1111/j.1365-2230.2004.01428.x

37. Snauwaert JJ, Yuen WY, Jonkman MF, Moons P, Naulaers G, Morren MA. Burden of itch in epidermolysis bullosa. $\mathrm{Br} J$ Dermatol. 2014;171(1):73-78. doi: 10.1111/bjd.12885

38. Danial C, Adeduntan R, Gorell ES, Lucky AW, Paller AS, Bruckner A, et al. Prevalence and characterization of pruritus in epidermolysis bullosa. Pediatr Dermatol. 2015;32(1):53-59. doi: 10.1111/pde.12391

39. Mauritz P, Jonkman MF, Visser SS, Finkenauer C, Duipmans JC, Hagedoorn $\mathrm{M}$, et al. Impact of painful wound care in epidermolysis bullosa during childhood: An interview study with adult patients and parents. Acta Derm Venereol. 2019;99(9):783-788. doi: 10.2340/00015555-3179

40. Oetjen LK, Mack MR, Feng J, Whelan TM, Niu H, Guo CJ, et al. Sensory neurons co-opt classical immune signaling pathways to mediate chronic itch. Cell. 2017;171(1):217-228.e13. doi: 10.1016/j.cell.2017.08.006

41. Papanikolaou M, Onoufriadis A, Mellerio JE, Nattkemper LA, Yosipovitch G, Steinhoff M, et al. Prevalence, pathophysiology and management of itch in epidermolysis bullosa. Br J Dermatol. 2021;184(5):816-825. doi: $10.1111 /$ bjd. 19496

42. Henderson J, Ferguson MW, Terenghi G. The feeling of healing. Plast Reconstr Surg. 2012;129(1):223e-224e. doi: 10.1097/PRS.0b013e3182365fda

43. van Scheppingen C, Lettinga AT, Duipmans JC, Maathuis CG, Jonkman MF. Main problems experienced by children with epidermolysis bullosa: a qualitative study with semi-structured interviews. Acta Derm Venereol. 2008;88(2):143-150. doi: 10.2340/00015555-0376

44. Fine JD, Johnson LB, Weiner M, Li KP, Suchindran C. Epidermolysis bullosa and the risk of life-threatening cancers: the 
National EB Registry experience, 1986-2006. J Am Acad Dermatol. 2009;60(2):203-211. doi: 10.1016/j.jaad.2008.09.035

45. Feinstein JA, Jambal $P$, Peoples K, Lucky AW, Khuu $P$, Tang JY, et al. Assessment of the timing of milestone clinical events in patients with epidermolysis bullosa from North America. JAMA Dermatol. 2019;155(2):196-203. doi: 10.1001/jamadermatol.2018.4673

46. Hoste E, Arwert EN, Lal R, South AP, Salas-Alanis JC, Murrell DF, et al. Innate sensing of microbial products promotes wound-induced skin cancer. Nat Commun. 2015;6:5932. doi: 10.1038/ncomms6932

47. Карамова А.Э., Альбанова В.И., Мончаковская Е.С. Принципы ведения больных врожденным буллезным эпидермолизом. Вестник дерматологии и венерологии. 2019;95(4):24-30 [Karamova AE, Albanova VI, Monchakovskaya ES. Management of patients with congenital epidermolysis bullosa. Vestnik Dermatologii i Venerologii. 2019;95(4):2430. (In Russ.)] doi: 10.25208/0042-4609-2019-95-4-24-30

48. Раваева Н.Э., Бертош И.М. Врожденный дистрофический буллезный эпидермолиз: опыт выхаживания новорожденного. Тольяттинский медицинский консилиум. 2014;3-4:158-161 [Ravaeva NE, Bertosh IM. Hereditary dystrophic epidermolysis bullosa: Experience of nursing a newborn. Tol'yattinskiy meditsinskiy konsilium. 2014;3-4:158-161 (In Russ.)]

49. Кубанов А.А., Альбанова В.И., Чикин В.В., Епишев Р.В. Современные методы терапии врожденного буллезного эпидермолиза. Вестник дерматологии и венерологии. 2014;6:47-56 [Kubanov AA, Albanova VI, Chikin VV, Yepishev RV. Modern methods of the treatment of hereditary epidermolysis bullosa. Vestnik Dermatologii i Venerologii 2014;6:47-56 (In Russ.)]

50. Сердюкова Е.А., Попов В.В. Лечение врожденного буллезного эпидермолиза у детей. Лекарственный вестник 2016;10(4)(64):43-47. [Serdyukova EA, Popov VV. Lechenie vrozhdennogo bulleznogo epidermoliza u detey. Lekarstvennyy vestnik 2016;10(4)(64):43-47 (In Russ.)]

51. Агранович О.Е., Буклаев Д.С., Тихоненко Т.И. Дистрофический буллезный эпидермолиз в сочетании с врожденными контрактурами верхних и нижних конечностей. Ортопедия, травматология и восстановительная хирургия детского возраста. 2015;3(4):51-59 [Agranovich OE, Buklaev DS, Tikhonenko TI. Dystrophic epidermolysis bullosa associated with congenital contractures of the upper and lower limbs: Literature review. Pediatric Traumatology, Orthopaedics and Reconstructive Surgery. 2015;3(4):51-59 (In Russ.)] doi: 10.17816/PTORS3451-59

52. Самцов А.В., Белоусова И.Э. Буллезные дерматозы: Монография. СПб.: Издательско-полиграфическая компания «КОСТА», 2012. 144 c. [Samtsov A.V., Belousova I.E. Bulleznye dermatozy: Monografiya. SPb.: Izdatel'sko-poligraficheskaya kompaniya «KOSTA», 2012. p. 144 (in Russ.)]

53. Афонин А.А., Лебеденко А.А., Шокарев А.В., Козырева Т.Б., Тараканова Т.Д. Случай врожденного буллезного эпидермолиза у новорожденного ребенка. Медицинский Вестник Юга России. 2016;(2):75-78 [Afonin AA, Lebedenko AA, Shokarev AV, Kozureva TB, Tarakanova TD. A case of the hereditary epidermolysis bullosa in a newborn children. Medical Herald of the South of Russia. 2016;(2):75-78 (In Russ.)] doi: 10.21886/2219-8075-2016-2-75-78

54. Альбанова В.И. Буллезный эпидермолиз: первый год жизни. Российский вестник перинатологии и педиатрии. 2010;3:110-117 [Epidermolysis bullosa: The first year of life. Rossiyskiy Vestnik Perinatologii i Pediatrii (Russian Bulletin of perinatology and pediatrics). 2010;3:110-117 (In Russ.)]

55. Рубанов Л.Н., Ярец Ю.И. Клинико-лабораторная эффрективность использования препаратов «Куриозин» и «Мидокалм» у больных с ранами. Международные обзоры: клиническая практика и здоровье. 2013;4(4).96-105 [Rubanov LN, Yarets Yul. Kliniko-laboratornaya effektivnost' ispol'zovaniya preparatov "Kuriozin" i "Midokalm" u bol'nykh S ranami. Mezhdunarodnye obzory: klinicheskaya praktika i zdorov'e. 2013:4(4):96-105 (In Russ.)]

56. Альбанова В.И., Гольченко В.А. Лечение буллезного эпидермолиза. Российский журнал кожных и венерических болезней. 2013;4:2124 [Albanova VI, Golchenko VA. Therapy of bullous epidermolysis. Russian Journal of Skin and Venereal Diseases. 2013;4:21-24 (In Russ.)]
57. Denyer J.E. Wound management for children with epidermolysis bullosa. Dermatol Clin. 2010;28(2):257-264, viii-ix.

doi: 10.1016/j.det.2010.01.002

58. Khan MT. Podiatric management in epidermolysis bullosa. Dermatol Clin. 2010;28(2):325-333. doi: 10.1016/j.det.2010.02.006

59. El Hachem M, Zambruno G, Bourdon-Lanoy E, Ciasulli A, Buisson C, Hadj-Rabia $S$, et al. Multicentre consensus recommendations for skin care in inherited epidermolysis bullosa. Orphanet $J$ Rare Dis. 2014:9:76. doi: 10.1186/1750-1172-9-76

60. Banky JP, Sheridan AT, Storer EL, Marshman G. Successful treatment of epidermolysis bullosa pruriginosa with topical tacrolimus. Arch Dermatol. 2004;140:794-796. doi: 10.1001/archderm.140.7.794

61. Danial C, Adeduntan R, Gorell ES, Lucky AW, Paller AS, Bruckner $\mathrm{AL}$, et al. Evaluation of treatments for pruritus in epidermolysis bullosa. Pediatr Dermatol. 2015;32(5):628-634. doi: 10.1111/pde.12486

62. Буллезный эпидермолиз: Руководство для врачей / Под ред. Мурашкина Н.Н., Намазовой-Барановой Л.С. М.: Педиатрь, 2019. 444 с. [Bulleznyy epidermoliz: rukovodstvo dlya vrachey / Pod red. Murashkina N.N., Namazovoy-Baranovoy L.S. Moscow: Pediatr"", 2019. p. 444 (In Russ.)]

63. Альбанова В.И., Смольянникова В.А., Гольченко В.А. Синдром Киндлер - редкий тип врожденного буллезного эпидермолиза. Вестник дерматологии и венерологии. 2015;(4):95-104 [Albanova VI, Smolyannikova VA, Golchenko VA. Kindler syndrome - a rare type of hereditary epidermolysis bullosa. Vestnik Dermatologii i Venerologii. 2015;4:95-104 (In Russ.)]

64. Гаджимурадов М.Н., Гаджимурадова К.М., Алиева М.Г., Мамашева Г.Д. Врожденный буллезный эпидермолиз: клинические особенности и собственные наблюдения. Клиническая дерматология и венерология. 2020;19(5):647-654 [Gadzhimuradov MN, Gadzhimuradova KM, Alieva MG, Mamasheva GD. Congenital epidermolysis bullosa. Clinical features and own observations. Russian Journal of Clinical Dermatology and Venereology / Klinicheskaya Dermatologiya i Venerologiya. 2020;19(5):647654 (In Russ.)] doi: 10.17116/klinderma202019051647

65. Pope E, Lara-Corrales I, Mellerio J, Martinez A, Schultz G, Burrell $\mathrm{R}$, et al. A consensus approach to wound care in epidermolysis bullosa. J Am Acad Dermatol. 2012;67(5):904-917.

doi: 10.1016/j.jaad.2012.01.016

66. Шурова Л.В., Старостин О.И., Корсунский А.А., Плотников Н.А. Хирургическое лечение больного с врожденным буллезным эпидермолизом, осложненным развитием деформаций кистей и стоп. Российский вестник детской хирургии, анестезиологии и реаниматологии. 2016;VI(4):98-101 [Shurova LV, Starostin 0I, Korsunsky AA, Plotnikov NA. Surgical treatment of a patient with inherited epidermolysis bullosa complicated with deformity of hands and feet. Russian Journal of Pediatric Surgery, Anesthesia and Intensive Care. 2016;VI(4):98-101 (In Russ.)]

67. Бенова Н.В., Григорьев К.И., Коваленок К.В. Помощь детям с буллезным эпидермолизом: паллиативные пути решения проблемы. Медицинская сестра. 2013;8:36-44 [Benova NV, Grigoryev Kl, Kovalenok KV. Care for children with epidermolysis bullosa: palliative ways to solve the problem. Meditsinskaya sestra. 2013;8:36-44 (In Russ.)]

68. Vakoliuk OB, Budaev IV, Kosteniuk SV. The main aspects of the clinic picture, treatment and prevention of caries and periodontal tissues of children patients with epidermolysis bullosa. East European Scientific Journal. 2016;9(1):47-50.

69. Kubanov A, Karamova A, Albanova V, Smoliannikova V, Nefedova M, Chikin V, et al. Allogeneic fibroblast cell therapy in the treatment of recessive dystrophic epidermolysis bullosa. Wound Medicine. 2018;21:8-11. doi: 10.1016/j.wndm.2018.04.002

70. Кубанов А.А., Карамова А.Э., Мончаковская Е.С. Врожденный буллезный эпидермолиз: современные методы диагностики и терапии. Перспективы регенеративной медицины. Вестник дерматологии и венерологии. 2020;96(1):10-17 [Kubanov AA, Karamova AE, Monchakovskaya ES. Congenital epidermolysis bullosa: modern methods of diagnosis and therapy. Prospects for regenerative medicine. Vestnik Dermatologii i Venerologii. 2020;96(1):10-17 (In Russ.)] doi: 10.25208/vdv551-2020-96-1-10-17 
71. Карамова А.Э., Чикин В.В., Альбанова В.И., Смольянникова В.А., Нефедева М.А., Мончаковская Е.С. и др. Плоскоклеточный рак кожи, развившийся у больной рецессивным дистрофическим буллезным эпидермолизом. Вестник дерматологии и венерологии 2016;(3):83-89 [Karamova AE, Chikin VV, Albanova VI, Smoliannikova VA, Nefedova MA Monchakovskaya ES, et al. Squamous-cell carcinoma in a female patient suffering from recessive dystrophic epidermolysis bullosa. Vestnik Dermatologii i Venerologii 2016;3:83-89 (In Russ.)]

72. Кубанов А.А., Карамова А.Э., Чикин В.В., Мончаковская Е.С., Нефедова М.А. Плоскоклеточный рак кожи у больных рецессивным дистрофическим буллезным эпидермолизом: случаи с агрессивным течением новообразования. Вопросы онкологии. 2020;66(5):556-562 [Kubanov AA, Karamova AE, Chikin WV, Monchakovskaya ES, Nefedova MA. A case report of aggressive squamous cell carcinoma in patients with recessive dystrophic epidermolysis bullosa. Problems in Oncology. 2020;66(5):556-562 (In Russ.)] doi: 10.37469/0507-3758-2020-66-5-556-562

73. Condorelli AG, Dellambra E, Logli E, Zambruno G, Castiglia D. Epidermolysis bullosa-associated squamous cell carcinoma: from pathogenesis to therapeutic perspectives. Int J Mol Sci. 2019;20(22):5707. doi: 10.3390/ijms20225707

74. Mellado F, Fuentes I, Palisson F, Vergara JI, Kantor A. Ophthalmologic approach in epidermolysis bullosa: A cross-sectional study with phenotype-genotype correlations. Cornea. 2018;37(4):442-447. doi: $10.1097 / / C 0.0000000000001525$

75. Кубанов А.А., Карамова А.Э., Чикин В.В., Богданова Е.В., Мончаковская Е.С. Эпидемиология и состояние оказания медицинской помощи больным врожденным буллезным эпидермолизом в Российской Федерации. Вестник РАМН. 2018;73(6):420-430 [Kubanov AA, Karamova AA, Chikin VV, Bogdanova EV, Monchakovskaya ES. Epidemiology and providing of healthcare for patients with inherited epidermolysis bullosa in the Russian Federation. Annals of the Russian academy of medical sciences. 2018;73(6):420-430 (In Russ.)] doi: 10.15690/vramn980

76. Gonzalez ME. Evaluation and treatment of the newborn with epidermolysis bullosa. Semin Perinatol. 2013;37(1):32-39.

doi: 10.1053/j.semperi.2012.11.004

77. Кубанов А.А., Карамова А.Э., Альбанова В.И., Мончаковская Е.С. Терапия больных врожденным буллезным эпидермолизом с применением современных неадгезивных перевязочных средств. Вестник дерматологии и венерологии. 2019;95(1):30-40 [Kubanov AA, Karamova AE, Albanova VI, Monchakovskaya ES. Therapy of patients with congenital epidermolysis bullosa using modern non-adherent wound dressings. Vestnik Dermatologii i Venerologii. 2019;95(1):30-40 (In Russ.)] doi: 10.25208/0042-4609-2019-95-1-30-40

Участие авторов: все авторы несут ответственность за содержание и целостность всей статьи. Концепция и дизайн статьи, одобрение окончательной версии статьи - Кубанов А.А.; анализ литературы, сбор и обработка материала, написание текста статьи - Чикин В.В.; концепция, дизайн, подготовка текста статьи — Карамова А.Э.; анализ литературы, сбор материала — Мончаковская Е.С.

Authors' participation: all authors: approval of the final version of the article, responsibility for the integrity of all parts of the article. Concept and design development, approval of the article - Alexey A. Kubanov; literature analysis, data collection, analysis, and interpretation, text writing - Vadim V. Chikin; concept and design development, preparation of the text of manuscript — Arfenya E. Karamova; literature analysis, data collection — Ekaterina S. Monchakovskaya.

\section{Информация об авторах}

*Мончаковская Екатерина Сергеевна - младший научный сотрудник; адрес: Россия, 107076, г. Москва, улица Короленко, д. 3, стр. 6; ORCID iD: https://orcid.org/0000-0002-6402-0962; eLibrary SPIN: 9859-1912; e-mail: monchakovskaya@cnikvi.ru

Кубанов Алексей Алексеевич - д.м.н., профрессор, член-корреспондент PAH; ORCID iD: https://orcid.org/0000-0002-7625-0503; eLibrary SPIN: 8771-4990; e-mail: alex@cnikvi.ru

Чикин Вадим Викторович - д.M.H.; ORCID iD: https://orcid.org/0000-0002-9688-2727; eLibrary SPIN: 3385-4723; e-mail: chikin@cnikvi.ru

Карамова Арфеня Эдуардовна - к.м.н.; ORCID iD: https://orcid.org/0000-0003-3805-8489; eLibrary SPIN: 3604-6491; e-mail: karamova@cnikvi.ru

\section{Information about the authors}

*Ekaterina S. Monchakovskaya - junior research associate; address: 3 bldg 6 Korolenko street, 107076, Moscow, Russia; ORCID iD: https://orcid.org/0000-0002-6402-0962; eLibrary SPIN: 9859-1912; e-mail: monchakovskaya@cnikvi.ru

Alexey A. Kubanov - MD, Dr. Sci. (Med.), Professor, Corresponding Member of the Russian Academy of Sciences; ORCID iD: https://orcid.org/0000-0002-7625-0503; eLibrary SPIN: 8771-4990; e-mail: alex@cnikvi.ru

Vadim V. Chikin — MD, Dr. Sci (Med.); ORCID iD: https://orcid.org/0000-0002-9688-2727; eLibrary SPIN: 3385-4723; e-mail: chikin@cnikvi.ru

Arfenya E. Karamova - MD, Cand. Sci. (Med.); ORCID iD: https://orcid.org/0000-0003-3805-8489; eLibrary SPIN: 3604-6491; e-mail: karamova@cnikvi.ru

Статья поступила в редакцию: 29.10.2021

Принята к публикации: 12.11.2021

Дата публикации: 15.12 .2021
Submitted: 29.10 .2021

Accepted: 12.11.2021

Published: 15.12 .2021 